Article

\title{
Ecological Water Demand of Taitema Lake in the Lower Reaches of the Tarim River and the Cherchen River
}

\author{
Zhaoxia Ye ${ }^{1,2}\left(\mathbb{D}\right.$, Shifeng Chen ${ }^{1}$, Qifei Zhang ${ }^{3}$, Yongchang Liu ${ }^{1}$ and Honghua Zhou ${ }^{1, *(\mathbb{C}}$ \\ 1 State Key Laboratory of Desert and Oasis Ecology, Xinjiang Institute of Ecology and Geography, \\ Chinese Academy of Sciences, Urumqi 830011, China; yezx@ms.xjb.ac.cn (Z.Y.); \\ chenshifeng2@yeah.net (S.C.); liuyongchang19@mails.ucas.ac.cn (Y.L.) \\ 2 Akesu National Station of Observation and Research for Oasis Agro-Ecosystem, Akesu 843017, China \\ 3 School of Public Administration, Shanxi University of Finance and Economics, Taiyuan 030012, China; \\ zhangqifei15@mails.ucas.ac.cn \\ * Correspondence: zhouhh@ms.xjb.ac.cn; Tel.: +86-991-7823160
}

check for updates

Citation: Ye, Z.; Chen, S.; Zhang, Q.; Liu, Y.; Zhou, H. Ecological Water Demand of Taitema Lake in the Lower Reaches of the Tarim River and the Cherchen River. Remote Sens. 2022, 14, 832. https://doi.org/ $10.3390 / \mathrm{rs} 14040832$

Academic Editor: Pavel Kishcha

Received: 28 December 2021

Accepted: 9 February 2022

Published: 10 February 2022

Publisher's Note: MDPI stays neutral with regard to jurisdictional claims in published maps and institutional affiliations.

Copyright: (C) 2022 by the authors. Licensee MDPI, Basel, Switzerland. This article is an open access article distributed under the terms and conditions of the Creative Commons Attribution (CC BY) license (https:// creativecommons.org/licenses/by/ $4.0 /)$.

\begin{abstract}
Taitema Lake, located in the lower reaches of the Tarim River and the Cherchen River, is one of the most important ecological barriers in Ruoqiang County. The amount of water in Taitema Lake plays an important role in maintaining a healthy cycle within the ecosystem, curbing sandstorms, and improving salinization and desertification. The aim of this study was to reasonably determine the volume of ecological water conveyance by calculating the ecological water demand. We systematically analyzed the spatial and temporal variation characteristics of Taitema Lake during 21 ecological water conveyance processes from 2000 to 2020. The results showed that the area of Taitema Lake increased at a rate of $144 \%$ per year because of the Ecological Water Conveyance Project (EWCP). The areas of water in dry, normal, and high flow years were $30.35,57.76$, and $103.5 \mathrm{~km}^{2}$, respectively. The corresponding ecological water demand was $1.58 \times 10^{8}, 3.09 \times 10^{8}$, and $5.66 \times 10^{8} \mathrm{~m}^{3}$, respectively. We calculated that the Cherchen River and the Tarim River carried $0.87 \times 10^{8}-3.11 \times 10^{8} \mathrm{~m}^{3}$ and $0.71 \times 10^{8}-2.55 \times 10^{8} \mathrm{~m}^{3}$ of water, respectively, under different inflow frequencies. This study has significance as a reference for estimates of the ecological water demand of terminal lakes under the condition of artificial water transport in arid inland river basins, and provides the basis for the rational allocation of water resources in the Tarim River Basin.
\end{abstract}

Keywords: ecological water conveyance; water area; ecological water demand; Taitema Lake; Tarim River; Cherchen River

\section{Introduction}

The Tarim River Basin is an important energy replacement area and reserve resource pool in China. This basin is also the strategic bridgehead of the Silk Road Economic Belt opening to the west, and its economic and political status is very important. Due to the unreasonable utilization of water resources in the basin and the extremely fragile ecological environment of the basin itself, Lop Nur and Taitema Lake at the tail end of the Tarim River dried up in 1970 and 1972, respectively, and the $321 \mathrm{~km}$ channel from the Daxihaizi Reservoir in the lower reaches of the Tarim River was cut off in 1972. Since 2000, the Ecological Water Conveyance Project (EWCP) to the lower reaches of the Tarim River has realized intermittent water supply, from Daxihaizi Reservoir, which has improved restoration of the lower reaches of the Tarim River and revived Taitema Lake, which was dried up for decades. The area of water in Taitema Lake has been continuously expanded, and the wetland vegetation in the area has been gradually restored. Many scientific studies in the past 20 years, from a macroscopic regional scale to a microscopic cellular scale and from field observations to laboratory experiments, have been carried out and have elucidated key factors, such as the threshold of groundwater level [1,2], the ecological water demand [3], the ecological effects of EWCP [4-8], eco-hydrological processes [9-12], 
the physiological and ecological response of plants [13,14], and the mechanisms of plant stress resistance [15-17]. Ling et al. [18] interpreted the mechanism for regulating water disturbance to alleviate drought stress and protect and restore desert riparian forest ecosystems by studying the relationship between ecological water transport and tree rings in the lower reaches of the Tarim River. Ling et al. [19] evaluated the positive effects of ecological water transport projects on the growth of desert riparian forests in arid basins. Li et al. [20] compared and supplemented improvements to ecological environmental factors, such as water quantity, water quality, groundwater change, and vegetation restoration over the past 20 years through ecological water transport. During the implementation of EWCP, experts and scholars engaged in ecological environmental research in arid areas, mostly focusing on the ecological effects of groundwater and natural vegetation on both sides of the rivers.

Studies have found that the response of Taitema Lake to EWCP is limited to lake area variations [21,22], ecological environment changes [23,24], and the replenishment of water sources [25]. The expansion of a lake's water area improves the ecology of the area and the water quality of the lake. It also increases the evaporation of water, thereby increasing water loss. The study area is characterized by a temperate arid continental climate with scarce precipitation and strong evaporation [26]. At the same time, the dense vegetation [8] leads to intense plant transpiration, further increasing water loss. In the desert area of the lower reaches of the Tarim River, where water resources are extremely scarce, it is very important to realize the effective utilization of water resources. However, according to the discharge volume of the Daxihaizi reservoir in recent years, if more water comes from the upstream, more water will be released downstream, and vice versa, ignoring the actual ecological water demands of the downstream area and the terminal lake. The key to changing this situation is to estimate the ecological water demands of the lower reaches of the Tarim River and the terminal lake. Ye et al. [3] estimated the ecological water demand of the natural vegetation in the lower reaches of the Tarim River in 2010. From 2000 to 2020, 21 water conveyance missions to the lower reaches of the Tarim River were implemented, 15 of which reached Taitema Lake, where a large body of water has formed. At this time, it is most urgent to estimate the ecological water demand of Taitema Lake.

Estimating a lake's ecological water demand involves analyzing many factors, such as eco-hydrology, meteorology, and vegetation. After Gleick [27,28] proposed the concept of basic ecological water demand through active exploration, a group of domestic experts and scholars represented by Yang et al. [29-31] summarized three categories of methods: the hydrologic method, the ecologic method, and the eco-hydrologic method. In this study, the hydrological guarantee rate method proposed by Zhang et al. [32] was adopted to determine the lake water area under different guarantee rates. Combined with meteorological data, the water evaporation and precipitation supply were also estimated. Lake leakage was estimated according to the lake leakage coefficient. Finally, a model of the lake's ecological water demand was established based on the principle of water balance. This model was applied in the East Juyanhai area of the lower Heihe River, which is also located in the inland river basin where the EWCP was carried out. Ye et al. [33] made a preliminary attempt to estimate the ecological water demand of Bosten Lake wetlands and achieved good results. These results are being used as the basis of water dispatching for water resource management in the Bosten Lake Basin to successfully guide local practices.

Lakes play an important role in runoff regulation, water supply, and the ecological balance of the basin $[34,35]$. Taitema Lake, located at the end of the lower reaches of the Tarim River and the Cherchen River, is one of the most important ecological barriers in Ruoqiang County. In the past, this lake was connected with Lop Nur. As the destination of rivers, Taitema Lake is a place where pollutants and salts accumulated. The amount of water in Taitema Lake plays an important role in maintaining a healthy cycle of the ecosystem in the lower reaches of the Tarim River and the Cherchen River, curbing sandstorms, and improving salinization and desertification. The restoration of water bodies in the lake area is beneficial to the restoration of the ecological environment of the lake and its surrounding 
areas, the protection of local biodiversity, and the alleviation of land desertification. The water, moreover, has a regulating function: it is beneficial to the climate and the water balance of the lake and its surrounding area. Ensuring that Taitema Lake maintains a certain area and volume of water guarantees the ecological security of the lower reaches. A water transport scheme considering the ecological water demand of the terminal lake has important significance for the ecological degradation problem of the lakes in China, especially in arid areas.

The main purposes of this study were: (1) to analyze the spatial-temporal variations of the water area in Taitema Lake caused by 21 sources of ecological water transport, (2) to scientifically estimate the ecological water area and ecological water demands under different guarantee rates $(25 \%, 50 \%$, and $75 \%)$, and (3) to calculate lake water inflow from the Tarim River and the Cherchen River. This study has significance as a reference for estimations of ecological water demands in terminal lakes under the conditions of artificial water transport in arid inland river basins. It also resulted in direct guidance for water resource management.

\section{Materials and Methods}

\subsection{Study Area}

Taitema Lake is located in the southeast margin of the Tarim Basin, about $50 \mathrm{~km}$ north of Ruoqiang County, Bayingolin Mongol Autonomous Prefecture. This lake is located in an alluvial plain formed by three river systems: the Tarim River, the Cherchen River, and the rivers on the northern slope of the Altun Mountains (Figure 1). The main source of Taitema Lake is the Tarim River, which also receives water from the Cherchen River, Washixia River, Ruoqiang River, and Milan River. When the amount of water that comes into the lake is large, Taitema Lake follows the ancient road of the Tarim River into Lop Nur. Taitema Lake is divided into four subregions (A, B, C, and D) on the basis of the elevation, the distribution patterns of the lake surface, the supply water source, and the location of the inlet before and after the diversion of the Cherchen River [25].

In this study, Landsat 8 remote sensing images of Taitema Lake in July 2020 were interpreted. Referring to the aforementioned categories, the water areas at subregions A-D were $74.2,30.8,68.6$, and $0.5 \mathrm{~km}^{2}$, respectively, with a total area of about $174 \mathrm{~km}^{2}$. The Normalized Difference Vegetation Index (NDVI) was extracted by MODIS-Terra NDVI (MOD13C1), and vegetation areas with NDVIs greater than 0.1 in subregions A-D were 86.56, 43.75, 295.63 , and $23.9 \mathrm{~km}^{2}$, respectively (Figure 1). The total area was about $449.84 \mathrm{~km}^{2}$. Studies have shown that most vegetation areas with NDVIs less than 0.1 are bare land and sparse vegetation [36], and the vegetation around the water area is generally distributed in continuous patches. Therefore, the areas with NDVIs less than 0.1 were not considered in this study. The total wetland area (including water area) of Taitema Lake was found to be about $623.87 \mathrm{~km}^{2}$. 


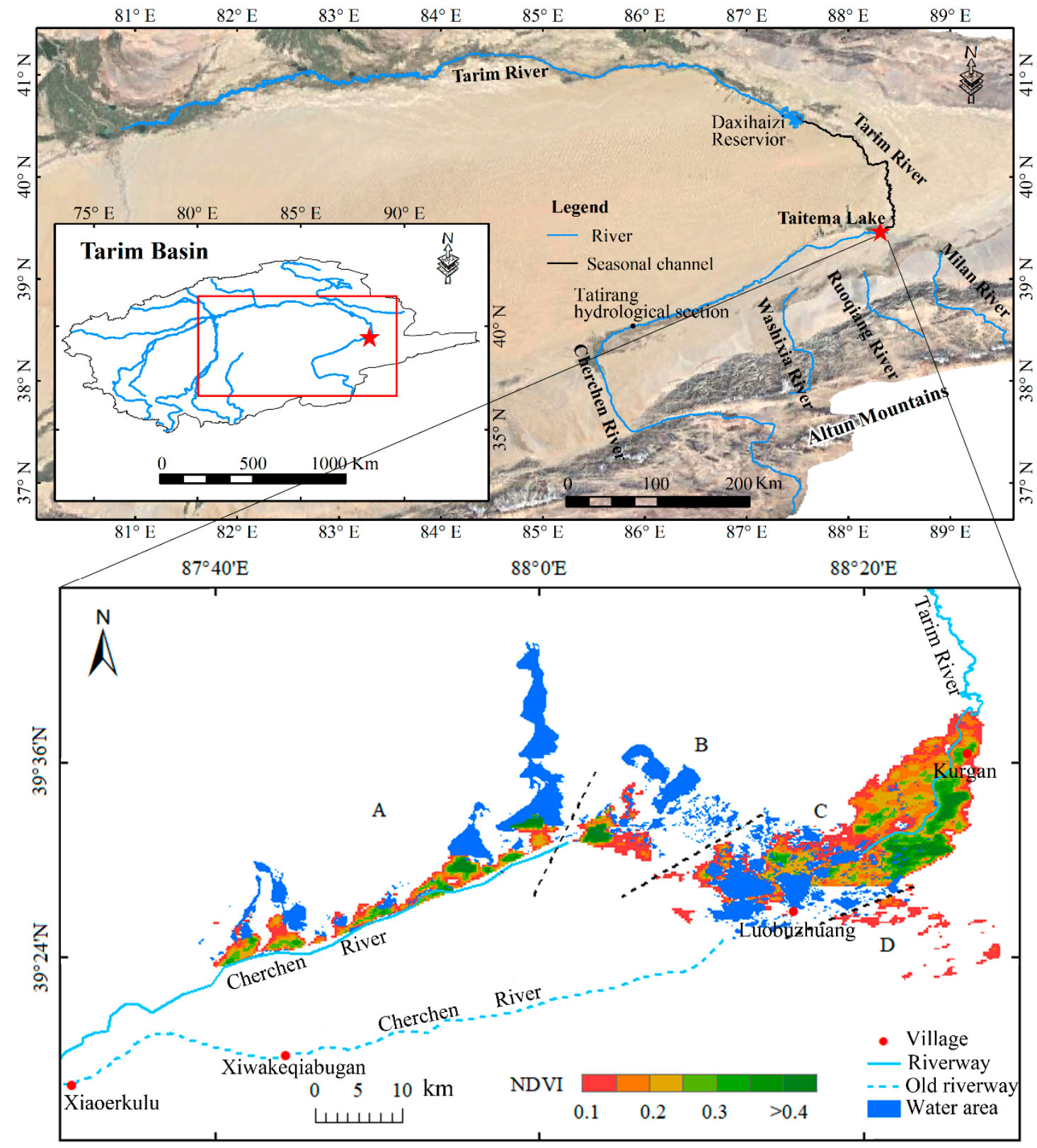

Figure 1. Schematic diagram of the study area.

\subsection{Data}

The areas of lakes are mainly monitored by optical remote-sensing satellites [37]. In this study, the water area data of Taitema Lake were supplied by the Joint Research Centre of European Commission and Google (EC JRC/Google) and calculated on the basis of the JRC Monthly Water History V1.2 dataset. This dataset provides the global surface water location, extent, and variation data from 1984 to 2019, with a resolution of $30 \mathrm{~m}$. Generated from 4,185,439 scenes of Landsat 5, 7, and 8 from 16 March 1984 to 31 December 2019, each pixel was separately divided into water/non-water using an expert system, and the results were collated into month and year records. All Landsat images over multiple decades were used to map seasonal changes of the surface water at continental [38] and subcontinental [39] scales with high accuracy. The JRC dataset extends previous work by using the entire multi-temporal orthorectified Landsat 5, 7 and 8 data [40]. For details, please see reference [40] and the online data user guide (https: / / code.earthengine.google.com/, accessed on 27 December 2021). By inputting the scope of the study area (.shp), years, and months into the Google Earth Engine platform, the monthly water area data in the 
target area were obtained as .csv and .shp files. According to the research needs, the water area over the 178 months since implementation of the ecological water transport project in 2000 was extracted, and the water area of each month was counted according to the four subregions mentioned previously.

As 2019 was the year of the latest data series released by EC JRC/Google during the writing of this paper, and the time series of precipitation and evaporation data were updated to 2020, the water area in 2020 was extracted using Landsat 8 Remote Sensing Images (the same data source as EC JRC/Google). This resulted in the data series with high integrity.

Given that there is no national meteorological station in the Taitema Lake region, the monthly precipitation and the monthly evaporation of the large evaporation pan were calculated by selecting the data of the nearest meteorological station in Ruoqiang County, $50 \mathrm{~km}$ away from Taitema Lake.

\subsection{Methods}

\subsubsection{Index for Water Area Change Characteristics}

To analyze the characteristics of water area variation in the study area, three indexes were introduced, namely, water area variation $\left(S_{\Delta}\right)$, change amplitude $(R)$, and dynamicity $\left(R_{S}\right)$. Water area variation refers to the difference between the water area at the end of period and the beginning of a period. In this paper, we analyzed the variations over four periods: 2000-2007, 2007-2009, 2009-2020, and 2000-2020. Here, a positive value indicates expansion of the water area, whereas a negative value indicates a reduction in the water area. The change in amplitude mainly reflects the overall situation of water area change over a period of time. The dynamicity is used to reflect the speed of this change. These indexes are calculated as follows [41]:

$$
\begin{gathered}
S_{\Delta}=S_{b}-S_{a} \\
R=\frac{S_{b}-S_{a}}{S_{a}} \times 100 \% \\
R_{s}=\frac{S_{b}-S_{a}}{S_{a} T} \times 100 \%
\end{gathered}
$$

where $S_{a}$ and $S_{b}$ represent the water area in the beginning and final years of the research period in $\mathrm{km}^{2} . T$ is the length of the research period, which was 20 years (from 2000 to 2020) in this study.

\subsubsection{Estimation of Ecological Water Area}

Based on Gleick's theory about the ecological significance of ecological water demand $[27,28]$, we propose a method of hydrological frequency analysis to determine the ecological water area [32]. That is, the time series for the minimum water area of Taitema Lake in the years since 2000 was ready, and the water areas corresponding to different guarantee rates $(25 \%, 50 \%$, and $75 \%)$ were calculated as the ecological water area via hydrological frequency analysis.

\subsubsection{Estimation of Ecological Water Demand}

The ecological water demand of Taitema Lake is mainly estimated by water consumption, including evaporation, leakage, and plant water demand. The net water consumption demand, which is the water that needs to be replenished by runoff in Taitema Lake, is obtained by adding the three consumption factors and subtracting water surface precipitation. The ecological water demand is calculated as follows [42]:

$$
W_{c}=A \times(E-P) \times 10^{3}+L+W_{v}
$$


where $W_{c}$ is the ecological water demand measured by water consumption $\left(\mathrm{m}^{3}\right) ; A$ is the ecological water area $\left(\mathrm{km}^{2}\right) ; E$ and $P$ are the annual water surface evaporation $(\mathrm{mm})$ and annual precipitation $(\mathrm{mm})$, respectively; $L$ is the annual leakage amount $\left(\mathrm{m}^{3}\right)$; and $W_{v}$ is the plant water requirements $\left(\mathrm{m}^{3}\right)$. As evaporation and precipitation differ year by year, the study selected guarantee rates of $25 \%, 50 \%$, and $75 \%$ for analysis and calculation, corresponding to a high flow year, normal flow year, and dry flow year, respectively.

The annual amount of seepage can be obtained by multiplying the annual amount of seepage per unit area with the ecological water area, from which the annual amount of seepage per unit area can be converted by the permeability coefficient, which needs to be obtained experimentally. Given that no data are available for calculating the annual seepage in the Cherchen River and Taitema Lake, the permeability coefficient at a depth of 2.90-3.80 m was calculated as $1.20 \times 10^{-7} \mathrm{~cm} / \mathrm{s}$ with reference to the research results of the East Pump Station of Bosten Lake in the same basin [43]. The annual leakage amount $(L)\left(\mathrm{m}^{3}\right)$ can be calculated as follows:

$$
L=\sum_{i=1}^{12} d \times 10^{-2} \times 31.536 \times 10^{6} \times A \times 10^{6}
$$

where $d$ is the permeability coefficient $(\mathrm{cm} / \mathrm{s})$, and $A$ is the ecological water area $\left(\mathrm{km}^{2}\right)$.

Considering that reed is the most widely distributed plant at Taitema Lake (except in the water), the plant water requirements should only be considered in the growing period. The plant water requirements include four parts: water consumption during plant assimilation, water contained within plants, water consumption by transpiration, and water consumption by inter-tree evaporation. Among them, water consumption by transpiration and water consumption by inter-tree evaporation account for $99 \%$ of the plant water requirement. Therefore, the plant water requirements can be approximately understood as the sum of transpiration and inter-tree evaporation, which is called evapotranspiration [42]. The plant water requirements $\left(W_{v}\right)\left(\mathrm{m}^{3}\right)$ are calculated as follows:

$$
W_{v}=K_{i} \times \sum_{i=1}^{12} E_{i} \times S_{v} \times 10^{3}
$$

where $K_{i}$ is the plant correction coefficient in month $i$. According to Ran et al.'s experiment [42], the plant correction coefficients of July, August, and September were 1.5, 1.43, and 1.06, respectively. The growing period of reed in Xinjiang extends roughly from May to September. This study only calculated the water requirement of reed from May to September, and the plant correction coefficients of May and June correspond to those of September and August. $E_{i}$ is the water surface evaporation in month $i(\mathrm{~mm})$ (for example, $E_{\text {May }}$ is the average evaporation in May from 2002 to 2019), and $S_{v}$ is the area of vegetation $\left(\mathrm{km}^{2}\right)$.

\section{Results}

\subsection{Changes in Water Area in Taitema Lake before and after Ecological Water Conveyance}

The EWCP in the lower reaches of the Tarim River was implemented in May 2000. Before the project was implemented, the total water area of subregions A-D was only $18 \mathrm{~km}^{2}$, and was mainly concentrated in subregions A and B. Subregions C and D had almost no water (Figure 2a). The first two water conveyances did not reach Taitema Lake. It was not until the third ecological water conveyance in April 2001 that the water head finally reached Taitema Lake. According to the remote sensing image extracted in June 2001, the water areas of subregions A and B totaled 32 and $24 \mathrm{~km}^{2}$, respectively. Meanwhile, after a long period of drying up, water bodies appeared again in subregions $C$ and $D$, and the total water area of the four subregions reached $68 \mathrm{~km}^{2}$ (Figure 2b). With further implementation of the EWCP and the continuous high flow year of the Cherchen River, the water areas of subregions A and B expanded continuously, whereas the water areas of subregions $C$ and D gradually expanded in a fluctuating manner, due to the intermittent characteristics of the 
water conveyance. By July 2003, the water area of the four subregions exceeded $200 \mathrm{~km}^{2}$ (Figure 2c). With the intermittent implementation of water conveyance, the water quantity at each time point reduced slightly compared to the previous time point, making the water areas of subregions C and D shrink. By July 2007, subregion D dried up again, and the total water area of Taitema Lake was about $80.5 \mathrm{~km}^{2}$ (Figure 2d). From 2007 to 2009, the lower reaches of the Tarim River were cut off again, and the areas of water in subregions $C$ and D continued to shrink. By June 2010, the eleventh emergency water conveyance totaled $3.64 \times 10^{8} \mathrm{~m}^{3}$. In August of the same year, about $28 \mathrm{~km}^{2}$ of the water area appeared in subregion D. The total water area of Taitema Lake was $280 \mathrm{~km}^{2}$ (Figure 2e).

The water area of subregion A was relatively stable, whereas the water areas of subregions B-D showed a decreasing trend. By July 2014, subregion D became dry again (Figure 2f). In March 2018, the total water area of Taitema Lake reached its highest value since 1988, $403 \mathrm{~km}^{2}$, and subregion C also reached its highest value since 1988, $196 \mathrm{~km}^{2}$ (Figure 2g). In October 2019, the total water area of Taitema Lake was about $292 \mathrm{~km}^{2}$, and the water areas of subregion A-D were 70,39, 128, and $55 \mathrm{~km}^{2}$, respectively (Figure $2 \mathrm{~h}$ ). In November 2020, the latest Sentinel data showed that the water area of Taitema Lake area reached $279 \mathrm{~km}^{2}$ after completion of the 21st ecological water conveyance, and the water areas of subregions A-D were $62.5,27.5,73.5$, and $115.7 \mathrm{~km}^{2}$, respectively.

In general, the water area in subregion A was shown to be relatively stable, whereas the area in subregion $B$ underwent rapid changes, mainly because the water source of subregion B is the surface water of the Cherchen River in the flood season. When the Cherchen River contains a large amount of water, the river water first replenishes the lake in subregion $\mathrm{A}$ and then reaches subregion $\mathrm{B}$, quickly forming a large, wide, and shallow lake. However, with the flow of surface water cut off, intense evaporation in the arid area makes subregion B shrink rapidly and gradually disappear.

The inter-annual variations of subregions $C$ and D are great, and are strongly affected by the Tarim River EWCP. When the discharge of water is large, the water first enters subregion $\mathrm{C}$ to form a large shallow lake. The lake water in subregion $\mathrm{C}$ can only cross the high ridge to replenish subregion $\mathrm{D}$ when the water reaches a certain height. However, when the discharge water gradually decreases, strong evaporation causes the rapid shrinkage of subregion D. Thus, subregion B always shrinks before subregion A, and subregion D always shrinks before subregion $\mathrm{C}$.

Considering that implementation of the EWCP mainly affects subregions C and D of Taitema Lake, the water areas of these two subregions were divided into several stages according to different water conveyance periods for further analysis. The first stage (intermittent water delivery period) covered the years 2000-2007, the second stage (downstream cut-off period) covered the years 2007-2009, and the third stage (intermittent water delivery period) covered the years 2009-2020. The water area variations $\left(S_{\Delta}\right)$, change amplitudes $(R)$, and dynamicity $\left(R_{S}\right)$ of these stages were calculated, as shown in Table 1.

Table 1 shows that the water area of subregion $C+D$ of Taitema Lake decreased from 2007 to 2009, but the variation, change amplitude, and dynamicity were not significant. Since no ecological water transport occurred during this period, the river was in a relatively natural state, indicating that the water area was relatively stable under natural conditions. However, the periods of 2000-2007 and 2009-2020 were when EWCP was implemented. The water area was greatly affected by the time and amount of water transport and had an overall increasing trend with a large change amplitude and high dynamicity. From 2009 to 2020 , the change amplitude and dynamicity were the largest, at $936 \%$ and $85 \%$ per year, respectively. Overall, from 2000 to 2020, the water area increased by $183 \mathrm{~km}^{2}$, with a change amplitude of $2884 \%$; that is, the water area increased by 28.84 times in 20 years, and the dynamicity was $144 \%$ per year. 

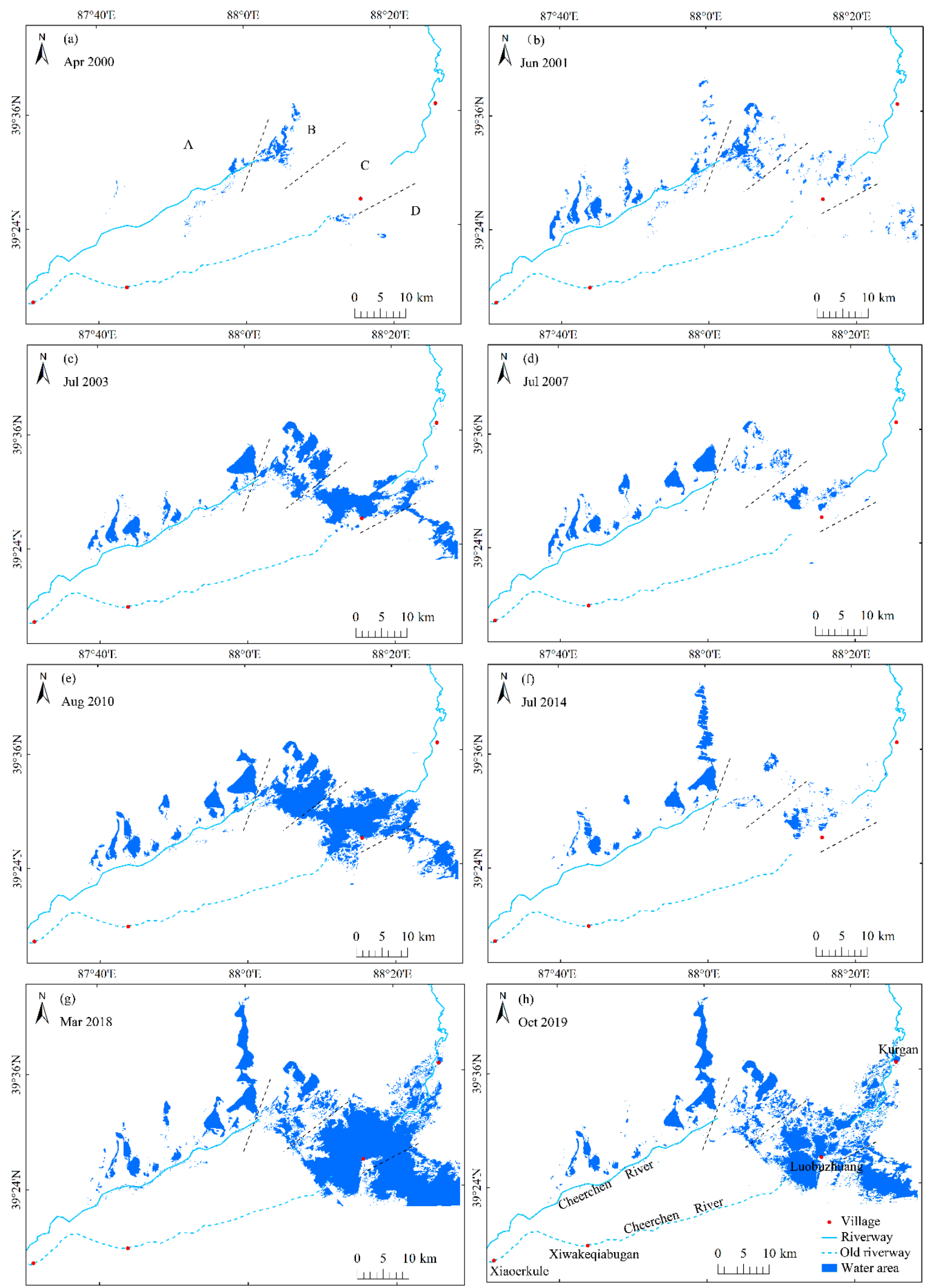

Figure 2. Spatial-temporal variation of water area in the Taitema Lake region. ((a-h) represents the water area distribution at different times, respectively). 
Table 1. Variations, change amplitudes, and dynamicity of the water area in subregion C + D.

\begin{tabular}{cccc}
\hline Period & $S_{\Delta} / \mathbf{k m}^{2}$ & $\boldsymbol{R} / \%$ & $\boldsymbol{R}_{\boldsymbol{s}} / \% /$ Year \\
\hline $2000-2007$ & 11 & 169 & 24 \\
\hline $2007-2009$ & -10 & -61 & -30 \\
\hline $2009-2020$ & 69 & 936 & 85 \\
\hline $2000-2020$ & 183 & 2884 & 144 \\
\hline
\end{tabular}

According to the water area variation in subregion $\mathrm{C}+\mathrm{D}$ of Taitema Lake over the years studied (Figure 3), from April 2000 to April 2001, although the EWCP was implemented, the water head had not yet reached Taitema Lake. Moreover, water bodies were occasionally seen in this area, with an average water area of about $0.9 \mathrm{~km}^{2}$. Once the water head reached Taitema Lake in May 2001, the water area began to increase, and the average water area was about $38 \mathrm{~km}^{2}$ from 2001 to 2007. From 2007 to 2009, the lower reaches of the Tarim River were cut off again, and the average water area was reduced to $3.5 \mathrm{~km}^{2}$. From 2010 to 2015, some water flowed into Taitema Lake, and the average water area was about $65 \mathrm{~km}^{2}$. From 2016 to 2020, the water transport volume increased compared to the previous period, and the average water area increased to $158 \mathrm{~km}^{2}$. With continuous implementation of the EWCP, the water area in subregion C $+\mathrm{D}$ of Taitema Lake presented a fluctuating increase.

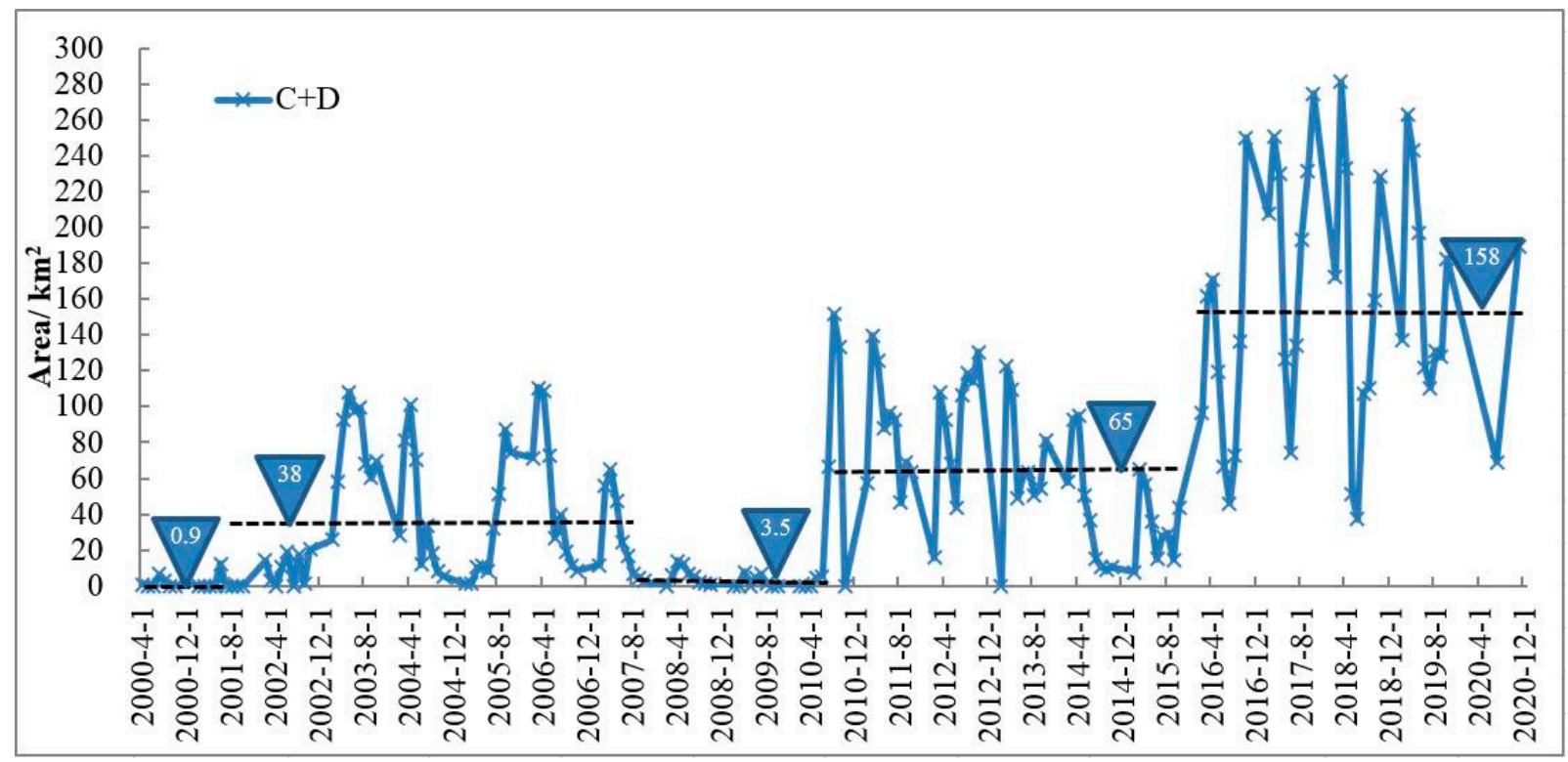

Figure 3. Water area variation in subregion C + D of Taitema Lake from 2000 to 2020.

\subsection{Ecological Water Area}

Due to the impact of the EWCP in the lower reaches of the Tarim River, Taitema Lake is not in a natural state. During the last 20 years, Taitema Lake has been disturbed by artificial water conveyance, which is discontinuous at a seasonal scale but basically continuous at an annual scale. Therefore, it is not practical to determine the ecological water area according to a natural state. The water area corresponding to different guarantee rates was obtained via hydrological frequency analysis, as shown in Figure 4 . The 75\% guarantee rate corresponds to a dry flow year, with an ecological water area of $30.35 \mathrm{~km}^{2}$. The $50 \%$ guarantee rate corresponds to a normal flow year, with an ecological water area of $57.76 \mathrm{~km}^{2}$. The $25 \%$ guarantee rate corresponds to a high flow year, with an ecological water area of $103.5 \mathrm{~km}^{2}$. 


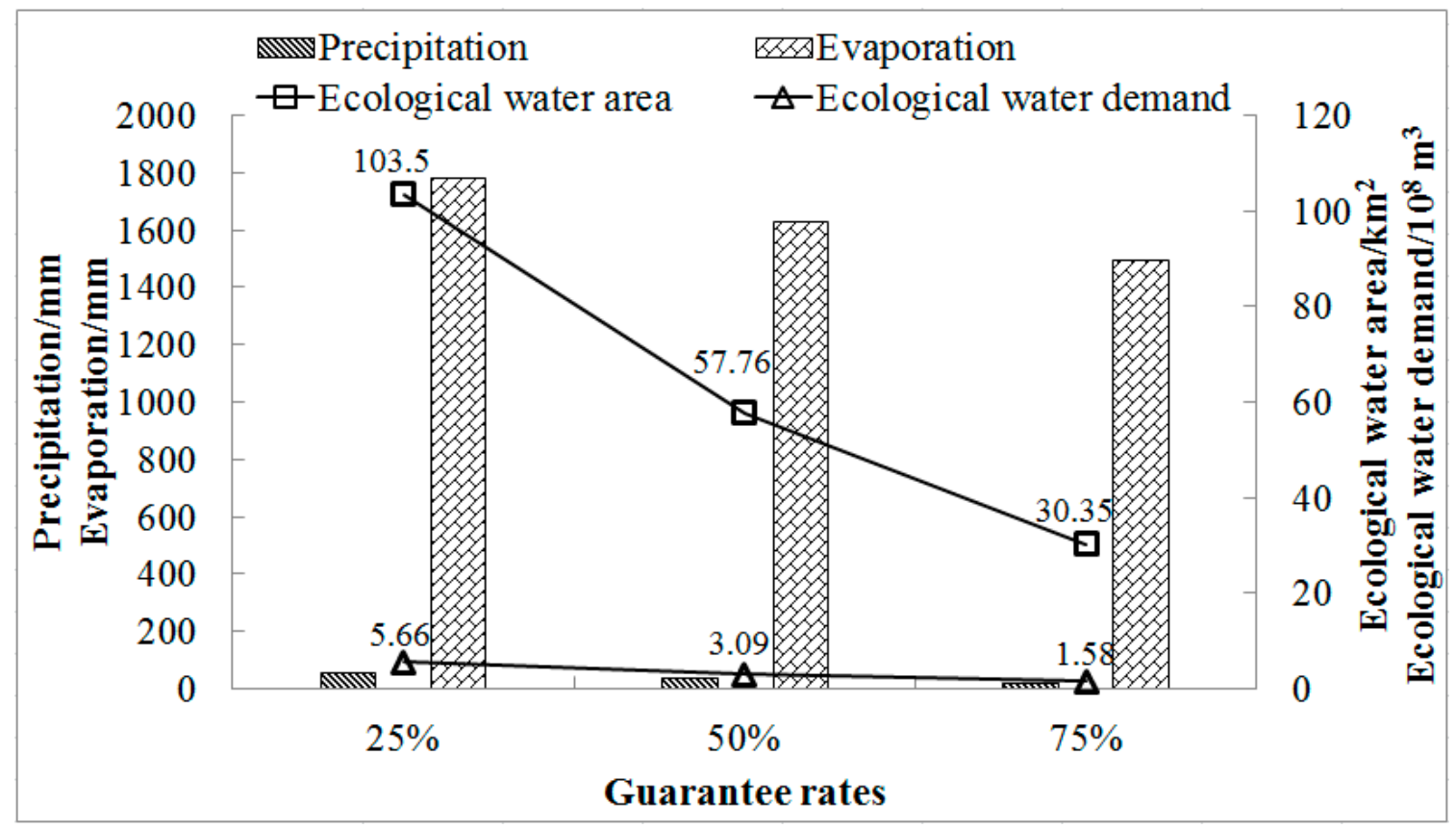

Figure 4. Ecological water area, ecological water demand, precipitation and evaporation at different guarantee rates in Taitema Lake.

\subsection{Estimation of Ecological Water Demand}

First, the precipitation and evaporation at different guaranteed rates in the Taitema Lake region were calculated. Then, precipitation and evaporation series from 2000 to 2020 were obtained through further statistical analyses. Second, the annual precipitation frequency curve (Pearson type III distribution curve) was drawn using the principle of the line fit method, and the values corresponding to annual precipitation frequencies of $25 \%$, $50 \%$, and $75 \%$ were calculated from the annual precipitation frequency curve (Figure 4). Similarly, precipitation frequency curve analysis was used to obtain the annual evaporation at different guarantee rates (Figure 4).

According to the vegetation area in the current year, the corresponding vegetation areas in dry, normal, and high flow years were calculated by equal reduction, with values of $78.46,149.33$, and $267.58 \mathrm{~km}^{2}$, respectively. Therefore, the evaporation water requirements for vegetation in dry, normal, and high flow years in the growing season of the Taitema Lake region were $1.13 \times 10^{8}, 2.14 \times 10^{8}$, and $3.84 \times 10^{8} \mathrm{~m}^{3}$, respectively (Table 2).

Table 2. Water requirements for vegetation evaporation in the growing season in Taitema Lake area.

\begin{tabular}{ccccccc}
\hline Month & May & June & July & \multicolumn{2}{c}{ August } & September \\
Total \\
\hline Vegetation evaporation $/ \mathrm{mm}$ & 241.1 & 344 & 355.3 & 318 & 175.8 & 1434.2 \\
\hline Vegetation evaporation in dry flow years $/ 10^{8} \mathrm{~m}^{3}$ & 0.19 & 0.27 & 0.28 & 0.25 & 0.14 & 1.13 \\
\hline Vegetation evaporation in normal flow years $/ 10^{8} \mathrm{~m}^{3}$ & 0.36 & 0.51 & 0.53 & 0.47 & 0.26 & 2.14 \\
\hline Vegetation evaporation in high flow years $/ 10^{8} \mathrm{~m}^{3}$ & 0.65 & 0.92 & 0.95 & 0.85 & 0.47 & 3.84 \\
\hline
\end{tabular}

According to Formula (5), the seepage of Taitema Lake in high, normal, and dry flow years amounted to $0.04 \times 10^{8}, 0.02 \times 10^{8}$, and $0.01 \times 10^{8} \mathrm{~m}^{3}$, respectively.

According to Formula (4), the ecological water demand of Taitema Lake in high, nor$\mathrm{mal}$, and dry flow years was $5.66 \times 10^{8}, 3.09 \times 10^{8}$, and $1.58 \times 10^{8} \mathrm{~m}^{3}$, respectively (Figure 4). 


\subsection{Lake Water Inflow from the Tarim River and the Cherchen River}

The water area of Taitema Lake under different guarantee rates was determined according to the hydrological frequency analysis method. By estimating the evapotranspiration of vegetation, evaporation of the water surface, precipitation, and leakage at different guarantee rates, the ecological water demand in high, normal, and dry flow years was calculated to be $5.66 \times 10^{8}, 3.09 \times 10^{8}$, and $1.58 \times 10^{8} \mathrm{~m}^{3}$, respectively. Throughout history, the Taitema Lake area was jointly supplied by the Tarim River and the Cherchen River. However, due to the lack of monitoring data for the amount of inflow from the Tarim River and the Cherchen River into Taitema Lake, we estimated the proportion of lake water inflow as follows. According to the areas of subregion $\mathrm{A}+\mathrm{B}$ and subregion $\mathrm{C}+\mathrm{D}$ extracted from 2000 to 2020, the proportions of area A + B and area C + D of the total area were calculated. Then, the average proportions of area $\mathrm{A}+\mathrm{B}$ and area $\mathrm{C}+\mathrm{D}$ were calculated, with results of $55 \%$ and $45 \%$, respectively. According to these proportions, the lake water inflow from the Cherchen River accounted for 55\% of the total ecological water demand, and from the Tarim River this accounted for $45 \%$. Based on our calculations, the water inflow from the Tarim River in high, normal, and dry flow years was $2.55 \times 10^{8}, 1.39 \times 10^{8}$, and $0.71 \times 10^{8} \mathrm{~m}^{3}$, respectively, and the water inflow from the Cherchen River in high, normal, and dry flow years was $3.11 \times 10^{8}, 1.70 \times 10^{8}$, and $0.87 \times 10^{8} \mathrm{~m}^{3}$, respectively.

\section{Discussion}

\subsection{Ecological Significance of Ecological Water Demand}

Gleick $[27,28]$ suggested that a certain amount of water of a certain quality-representing the basic ecological water demand or minimum ecological water demand-must be provided to the natural environment to minimize changes or disturbances of the natural ecosystem and protect species diversity and ecological integrity. The surface area of a lake will always change from year to year, and the extent of such changes will depend on inflow and precipitation. However, the surface areas of some lakes can remain relatively stable, even in the dry season. This part of a region is called the central area of lake wetlands, which is the smallest area that enables the lake wetland ecosystem to maintain its most basic living state. The corresponding lake level in this area is called the minimum ecological demand level, and the corresponding amount of water is called the minimum ecological water volume $[28,42]$.

\subsection{Comparison of Related Studies}

Landsat images are widely used in lake water area extraction [37-39,44,45]. JRC data were generated from Landsat 5, 7, and 8, and a consistent algorithm was applied to all 32 years of Landsat observations to produce a validated dataset that documents global surface water dynamics with the best levels of spatial detail and accuracy to date [40]. Therefore, this dataset is reliable.

The implementation of EWCP played a key role in the revival of Taitema Lake, especially the expansion of water area in subregion $\mathrm{C}+\mathrm{D}$. This scheme revived the previously dry lake and restored the ecosystem, including raising the surrounding water table [46], increasing vegetation coverage [23,46], and enabling the return of birds and other wildlife [23]. Before and after water replenishment, the area of Taitema Lake varied greatly both interannually and intra-annually [25]. Under continuous water transfer, the water area in subregion C + D increased by $183 \mathrm{~km}^{2}$, at a rate of $144 \%$ per year, which demonstrated that EWCP in the Tarim River had a great impact on the area of Taitema Lake, where the water area shrank between 2007 and 2009 (Table 1). The warm and wet climate characteristics of rising temperature and increasing precipitation strengthened regional evapotranspiration, which was one of the causes of water area shrinkage [47].

The authors in [48] shows that the area of Taitema Lake can be as small as $10-30 \mathrm{~km}^{2}$, the area is ordinarily $50-100 \mathrm{~km}^{2}$, and the area can be as large as $100-200 \mathrm{~km}^{2}$, which is difficult to realize. These results are consistent with the results of this study, which 
showed that the water area in dry, normal and high flow years is $30.35 \mathrm{~km}^{2}, 57.76 \mathrm{~km}^{2}$, and $103.5 \mathrm{~km}^{2}$, respectively.

\subsection{Calculation of the Actual Inflow of Lake Water}

According to a previous study, the average river loss per unit river length from Yingsu to the Yiganbujima reaches of the lower reaches of the Tarim River was $52.43 \times 10^{4} \mathrm{~m}^{3} / \mathrm{km}$ [49]. Thus, the total river loss of the $321 \mathrm{~km}$ discontinuous river channel from the Daxihaizi Reservoir to the end of the lower reaches of the Tarim River was estimated to be $1.64 \times 10^{8} \mathrm{~m}^{3}$. To meet the demands of Taitema Lake in high, normal, and dry flow years, the discharge of the Daxihaizi Reservoir should reach $4.19 \times 10^{8}, 3.03 \times 10^{8}$, and $2.35 \times 10^{8} \mathrm{~m}^{3}$, respectively. According to the Recent Comprehensive Management Plan for the Tarim River Basin, $3.5 \times 10^{8} \mathrm{~m}^{3}$ of ecological water needs to be discharged from the Daxihaizi Reservoir to the lower reaches of the Tarim River every year, which could meet the requirements of lake water inflow in normal and dry flow years, but not in high flow years.

In this study, the estimate for ecological water demand in high flow years was the upper limit of the lake's ecological water demand. As Taitema Lake is located in ecologically fragile areas at the end of the lower reaches of a terminal lake, the goal of ecological restoration should be to ensure the minimum ecological water area, not to achieve the maximum ecological water area. Thus, the water amount should not be less than the ecological water demand in dry flow years. Since the lake's ecosystem will be in jeopardy once the amount of water in the lake falls below the minimum ecological demand, and the wetland ecosystem will be faced with potential extinction, water replenishment measures must be implemented before water becomes that scarce. For this purpose, the water demand could be reduced in high flow years. In years with mostly abundant water, only the water intake requirement for a normal water level should be met. In other words, the discharge water index of the Daxihaizi Reservoir formulated in the Recent Comprehensive Management Plan of Tarim River Basin could meet the requirements for the annual inflow of lake water in years with different levels of water flow.

From 26 to 30 September 2018, technicians from Bayingolin Hydrographic Survey Bureau set up a temporary flow measurement section at Tatirang Bridge. The distance between the starting point (Qiemo hydrological station) and the ending point (Tatirang Bridge) was $57.8 \mathrm{~km}$. We calculated the ratio of flow difference $\left(0.9 \mathrm{~m}^{3}\right.$ per second $)$ and distance, and then divided the result by the initial flow from Qiemo hydrological station $\left(33.9 \mathrm{~m}^{3}\right.$ per second). The runoff loss rate of the Cherhen River was $0.046 \%$ per kilometer. According to the monitoring data of the Tatirang hydrological section, the hydrological section closest to the lower reaches of the Cherchen River, the runoff in high, normal, and dry flow years was $4.72 \times 10^{8} \mathrm{~m}^{3}, 3.28 \times 10^{8} \mathrm{~m}^{3}$ and $2.12 \times 10^{8} \mathrm{~m}^{3}$, respectively. The distance from the Tatirang hydrological section to the lake is $320 \mathrm{~km}$. According to the runoff loss rate, the runoff into the lake in high, normal, and dry flow years was $4.03 \times 10^{8} \mathrm{~m}^{3}, 2.8 \times 10^{8} \mathrm{~m}^{3}$, and $1.81 \times 10^{8} \mathrm{~m}^{3}$, respectively, which are all exceed the demand of the Cherchen River water inflow calculated in Section 3.4.

\subsection{Limitations and Constraints of This Study}

The ecological water demands of terminal lakes in arid areas were the focus of our research. Due to the lack of observational data, remote sensing data were used to extract the water area of Taitema Lake. In the future, field validation could be considered to improve data accuracy. In addition, observation instruments could be arranged to monitor the actual leakage rate of Taitema Lake over a long period of time to improve the accuracy of leakage calculations. At the same time, with financial support, automatic meteorological observation stations and evaporation pans could be set up to observe the actual precipitation and evaporation in the lake area. All these methods could make the estimation of ecological water demand more accurate. Although the accuracy of the data needs to be further improved, the calculation method in this paper is worth popularizing and applying to the study of ecological water demand for lakes in arid areas. 


\section{Conclusions}

From 2000 to 2020, the water area of subregion C+D was greatly affected by ecological water conveyance and increased by $183 \mathrm{~km}^{2}$, which is about 29 times compared to the initial stage of ecological water conveyance.

The ecological water area is not a fixed value and varies with different water inflow frequencies. According to the calculations, the ecological water area of Taitema Lake is $30.35-103.5 \mathrm{~km}^{2}$. In dry flow years, the water area was only $30.35 \mathrm{~km}^{2}$ or less. In high flow years, the water area expanded to $103.5 \mathrm{~km}^{2}$ or even larger. However, an expansion of the water area means that evapotranspiration and surface evaporation will also increase and water use efficiency may decrease. Therefore, the maximum useful area could be further analyzed and determined according to dynamic assessments of water balance and water resource utilization efficiency. That is exactly the focus of our future research.

The ecological water demand was $1.58 \times 10^{8}-5.66 \times 10^{8} \mathrm{~m}^{3}$ under different water inflow frequencies (i.e., the amount of water required to enter the lake). According to historical data, the Cherchen River and the Tarim River provided $55 \%$ and $45 \%$ of the water, respectively. We calculated that the Cherchen River and the Tarim River provided $0.87 \times 10^{8}-3.11 \times 10^{8} \mathrm{~m}^{3}$ and $0.71 \times 10^{8}-2.55 \times 10^{8} \mathrm{~m}^{3}$, respectively, under different inflow frequencies.

Considering the errors in estimations of river loss and the influence of human activities, we suggest setting up discharge monitoring stations at the entrance of the Cherchen River into Taitema Lake and the entrance of the Tarim River into Taitema Lake, in order to better monitor the inflow of lake water in the future. This would also provide a data-based foundation for studying the relationship between the inflow of water and the water area of Taitema Lake, as the latter relates to the ecological environment.

Author Contributions: Conceptualization, Z.Y.; methodology, Z.Y. and Q.Z.; software, Y.L.; validation, Z.Y. and S.C.; formal analysis, Z.Y.; investigation, Z.Y. and H.Z.; resources, Z.Y.; data curation, Z.Y., S.C. and Q.Z.; writing-original draft preparation, Z.Y.; writing-review and editing, Z.Y. and H.Z.; visualization, Y.L.; supervision, H.Z.; project administration, Z.Y.; funding acquisition, Z.Y. All authors have read and agreed to the published version of the manuscript.

Funding: This research was funded by the Xinjiang Uygur Autonomous Region Innovation Environment (Talent, Base) Construction Special Project [Grant No. 2019Q032].

Institutional Review Board Statement: Not applicable.

Informed Consent Statement: Not applicable.

Data Availability Statement: Not applicable.

Acknowledgments: We thank the anonymous experts for their valuable suggestions, which helped to substantially improve the manuscript. The Landsat images used in this study are available from USGS (http: / / earthexplorer.usgs.gov, accessed on 27 December 2021). The water area data of Taitema Lake were extracted from the Joint Research Centre (JRC) of the European Commission (EC)/Google and calculated on the basis of the JRC Monthly Water History V1.2 dataset, which was recently updated to V1.3 now. (https:/ / developers.google.cn/earth-engine/datasets/catalog/JRC_GSW1_3 _MonthlyHistory\#description, accessed on 27 December 2021). (The data used to generate Figure 2).

Conflicts of Interest: The authors declare no conflict of interest.

\section{References}

1. Hao, X.M.; Li, W.H. Assessment of the groundwater threshold of desert riparian forest vegetation along the middle and lower reaches of the Tarim River, China. Hydrol. Process. 2010, 24, 178-186. [CrossRef]

2. Hou, P.; Beeton, R.J.S.; Carter, R.W.; Dong, X.G.; Li, X. Response to environmental flows in the lower Tarim River, Xinjiang, China: Ground water. J. Environ. Manag. 2007, 83, 371-382. [CrossRef] [PubMed]

3. Ye, Z.X.; Chen, Y.N.; Li, W.H. Ecological water demand of natural vegetation in the lower Tarim River. J. Geogr. Sci. 2010, 20, 261-272. [CrossRef]

4. Chen, Y.N.; Chen, Y.P.; Xu, C.C.; Ye, Z.X.; Li, Z.Q.; Zhu, C.G.; Ma, X.D. Effects of ecological water conveyance on groundwater dynamics and riparian vegetation in the lower reaches of Tarim River, China. Hydrol. Process. 2010, 24, 170-177. [CrossRef] 
5. Chen, Y.N.; Li, W.H.; Xu, C.C.; Ye, Z.X.; Chen, Y.P. Desert riparian vegetation and groundwater in the lower reaches of the Tarim River basin. Environ. Earth. Sci. 2015, 73, 547-558. [CrossRef]

6. Chen, Y.N.; Li, W.H.; Zhou, H.H.; Chen, Y.N.; Hao, X.M.; Fu, A.H.; Ma, J.X. Experimental study on water transport observations of desert riparian forests in the lower reaches of the Tarim River in China. Int. J. Biometeorol. 2017, 61, 1055-1062. [CrossRef]

7. Hao, X.M.; Li, W.H. Impacts of ecological water conveyance on groundwater dynamics and vegetation recovery in the lower reaches of the Tarim River in northwest China. Environ. Monit. Assess. 2014, 186, 7605-7616. [CrossRef]

8. Dou, X.; Ma, X.F.; Huo, T.C.; Zhu, J.T.; Zhao, C.Y. Assessment of the environmental effects of ecological water conveyance over 31 years for a terminal lake in Central Asia. Catena 2022, 208, 105725. [CrossRef]

9. Ye, Z.X.; Chen, Y.N.; Li, W.H.; Yan, Y.; Wan, J.H. Groundwater fluctuations induced by ecological water conveyance in the lower Tarim River, Xinjiang, China. J. Arid Environ. 2009, 73, 726-732. [CrossRef]

10. Liu, C.M.; Chen, Y.N.; Xu, Z.X. Eco-hydrology and sustainable development in the arid regions of China. Hydrol. Process. 2010, 24, 127-128. [CrossRef]

11. Han, M.; Zhao, C.Y.; Feng, G.; Disse, M.; Shi, F.Z.; Li, J.Y. An eco-hydrological approach to predicting regional vegetation and groundwater response to ecological water conveyance in dryland riparian ecosystems. Quatern. Int. 2015, 380-381, 224-236. [CrossRef]

12. Liao, S.M.; Xue, L.Q.; Dong, Z.C.; Zhu, B.L.; Zhang, K.; Wei, Q.; Fu, F.B.; Wei, G.H. Cumulative ecohydrological response to hydrological processes in arid basins. Ecol. Indic. 2020, 111, 106005. [CrossRef]

13. Pan, Y.P.; Chen, Y.P.; Chen, Y.N.; Wang, R.Z.; Ren, Z.G. Impact of groundwater depth on leaf hydraulic properties and drought vulnerability of Populus euphratica in the Northwest of China. Trees 2016, 30, 2029-2039. [CrossRef]

14. Zhou, Y.Y.; Chen, Y.N.; Zhu, C.G.; Chen, Y.P.; Chen, X.L. Pupulation structure characteristics of Populus euphratica in the lower reaches of Tarim River. J. Desert Res. 2018, 38, 315-323. (In Chinese)

15. Rajput, V.D.; Chen, Y.N.; Ayup, M. Effects of high salinity on physiological and anatomical indices during the early stages of Populus euphratica growth. Russ. J. Plant Physiol. 2015, 62, 229-236. [CrossRef]

16. Yang, Y.H.; Chen, Y.N.; Li, W.H.; Zhu, C.G. Effects of progressive soil water deficit on growth, and physiological and biochemical responses of Populus euphratica in arid area: A case study in China. Pak. J. Bot. 2015, 47, 2077-2084.

17. Zhu, C.G.; Chen, Y.N.; Li, W.H.; Chen, X.L.; He, G.Z. Heliotropic leaf movement of Sophora alopecuroides L.: An efficient strategy to optimise photochemical performance. Photosynthetica 2015, 53, 231-240. [CrossRef]

18. Ling, H.B.; Xu, H.L.; Guo, B.; Deng, X.Y.; Zhang, P.; Wang, X.Y. Regulating water disturbance for mitigating drought stress to conserve and restore a desert riparian forest ecosystem. J. Hydrol. 2019, 572, 659-670. [CrossRef]

19. Ling, H.B.; Guo, B.; Yan, J.J.; Deng, X.Y.; Xu, H.L.; Zhang, G.P. Enhancing the positive effects of ecological water conservancy engineering on desert riparian forest growth in an arid basin. Ecol. Indic. 2020, 118, 106797. [CrossRef]

20. Li, L.J.; Zhang, X.Q.; Chen, C.Q.; Shen, M.Y. Ecological effects of water conveyance on the lower reaches of Tarim River in recent twenty years. Arid Land Geogr. 2018, 41, 238-247. (In Chinese)

21. Zhu, C.M.; Lj, J.L.; Shen, Z.F.; Shen, Q. Time series monitoring and comparative analysis on eco-environment change in the lower reaches of the Tarim River. J. Geo-Inf. Sci. 2019, 21, 437-444. (In Chinese)

22. Huo, T.C.; Yan, W.; Ma, X.F. A study of the variation and driving factors of the water area of the terminal lake of inland river: A case study of Taitema Lake region. Remote Sens. Land Resour. 2020, 32, 149-156. (In Chinese)

23. Wang, H.L.; Kasim, T. Exploration and analysis of ecological environment change of Taitema Lake before and after ecological water transfer. Ecol. Sci. 2020, 39, 93-100. (In Chinese)

24. Wang, Y.M.; Zhang, Q.Q.; Xu, H.L.; Zhao, X.F.; Liu, X.H.; Li, J. Change of plant diversity in the Taitema Lake Area before and after implementing the ecological water conveyance. Arid Zone Res. 2019, 36, 1186-1193. (In Chinese)

25. Chen, G.L. Relationship between the surface area of Taitema Lake and main supply water. Water Conserv. Sci. Technol. Econ. 2016, 22, 41-44. (In Chinese)

26. Sun, F.; Wang, Y.; Chen, Y.N.; Li, Y.P.; Zhang, Q.F.; Qin, J.X.; Kayumba, P.M. Historic and simulated desert- Oasis ecotone changes in the arid Tarim River Basin, China. Remote Sens. 2021, 13, 647. [CrossRef]

27. Gleick, P.H. Water in crisis: Path to sustainable water use. Ecol. Appl. 1996, 8, 571-579. [CrossRef]

28. Gleick, P.H. The changing water paradigm: A look at twenty-first century water resource development. Water Int. 2000, 25, 127-138. [CrossRef]

29. Yang, Z.F.; Cui, B.S.; Sun, T.; Chen, H.; Yang, W. Mechanism, Model and Configuration of Wetland Ecological Water Demand; Science Press: Beijing, China, 2012. (In Chinese)

30. Yang, W.; Yang, Z.F.; Sun, T. A review of requirement quantity and allocation of ecological water for wetland. Wetl. Sci. 2008, 6 , 531-535. (In Chinese)

31. Cui, B.S.; Zhao, X.; Yang, Z.F. Eco-hydrology-based calculation of the minimum ecological water requirement for lakes. Acta Ecol. Sin. 2005, 25, 1788-1795. (In Chinese)

32. Zhang, H.; Zhang, L.; Zhao, C.Y. Ecological water requirement estimation of the rump lake in an extreme arid region of East Juyanhai. Acta Ecol. Sin. 2014, 34, 2102-2108. (In Chinese)

33. Ye, Z.X.; Yang, Y.H.; Zhou, H.H.; Guo, B. Ecological water rights of the Bosten Lake wetlands in Xinjiang, China. Wetlands 2020, 40, 2597-2607. [CrossRef] 
34. Zhu, W.B.; Yan, J.B.; Jia, S.F. Monitoring recent fluctuations of the southern Pool of Lake Chad using multiple remote sensing data: Implications for water balance analysis. Remote Sens. 2017, 9, 1032. [CrossRef]

35. Che, X.H.; Feng, M.; Sun, Q.; Sexton, J.O.; Channan, S.; Liu, J.P. The decrease in lake numbers and areas in Central Asia investigated using a landsat-derived water dataset. Remote Sens. 2021, 13, 1032. [CrossRef]

36. Li, P.L.; Hu, Z.M.; Liu, Y.W. Shift in the trend of browning in Southwestern Tibetan Plateau in the past two decades. Agric. For. Meteorol. 2020, 287, 107950. [CrossRef]

37. Zhang, C.H.; Lv, A.F.; Zhu, W.B.; Yao, G.B.; Qi, S.S. Using multisource satellite data to investigate lake area, water level, and water storage changes of terminal lakes in ungauged regions. Remote Sens. 2021, 13, 3221. [CrossRef]

38. Mueller, N.; Lewis, A.; Roberts, D.; Ring, S.; Melrose, R.; Sixsmith, J.; Lymburner, L.; McIntyre, A.; Tan, P.; Curnow, S.; et al. Water observations from space: Mapping surface water from 25 years of Landsat imagery across Australia. Remote Sens. Environ. 2016, 174, 341-352. [CrossRef]

39. Tulbure, M.G.; Broich, M.; Stehman, S.V.; Kommareddy, A. Surface water extent dynamics from three decades of seasonally continuous Landsat time series at subcontinental scale in a semi-arid region. Remote Sens. Environ. 2016, 178, 142-157. [CrossRef]

40. Pekel, J.-F.; Cottam, A.; Gorelick, N.; Belward, A.S. High-resolution mapping of global surface water and ints long-term changes. Nature 2016, 540, 418-422. [CrossRef]

41. Ziyinaii, H.; Wu, Z.P.; Baolangtijian, K. Lake changes in spatial evolution and driving force for the water area change of the Manas lake in Xinjiang in the past forty years. Remote Sens. Land Resour. 2018, 30, 217-223. (In Chinese)

42. Ran, X.J.; Shen, L.; Li, X.H. Study on the rule of water demand of swamp reed in Bosten Lake. J. Water Resour. Water Eng. 2010, 21, 66-69. (In Chinese)

43. Yuan, T.H.; Xi, L.; Song, Z.J. Engineering characteristics of the foundation soil of Eastern Pump Station at Bositeng Lake in Xinjiang. Rock Soil Mech. 2003, 24, 105-109. (In Chinese)

44. Wang, J.X.; Li, M.Y.; Wang, L.M.; She, J.F.; Zhu, L.P.; Li, X.G. Long-term lake area change and its relationship with climate in the Endorheic basins of the Tibetan Plateau. Remote Sens. 2021, 13, 5125. [CrossRef]

45. Zhong, Y.; Liu, Q.; Sapkota, L.; Luo, Y.Y.; Wang, H.; Liao, H.J. Rapid Glacier shrinkage and glacial lake expansion of a China-Nepal transboundary catchment in the Central Himalayas, between 1964 and 2020. Remote Sens. 2021, 13, 3614. [CrossRef]

46. Abula, A.; Zhu, Q.Q.; Xu, H.L.; Zhao, X.F.; Li, J.; Wang, Y.J. Characteristics of vegetation variation in Taitema Lake. J. Xinjiang Univ. (Nat. Sci. Ed.) 2019, 36, 182-191. (In Chinese)

47. Hu, S.; Mo, X.G.; Lin, Z.H. Projections of spatial-temporal variation of drought in north China. Arid Land Geogr. 2015, 38, 239-248. (In Chinese)

48. Fan, Z.L.; Xu, H.L.; Fu, J.Y.; Kurban, A.; Ablekim, A. Study on protection of wetland of Taitema Lake. Quat. Sci. 2013, 33, 594-602. (In Chinese)

49. Ye, Z.X.; Chen, Y.N.; Li, W.H.; Balati, M.; Mao, X.H. Study on the minimum ecological discharge of the cut-off channel in the lower reaches of Tarim River. Prog. Nat. Sci. 2008, 18, 531-537. (In Chinese) 